\title{
Infiltrating Bladder Urothelial Carcinoma, Lipid-Rich Variant
}

National Cancer Institute

\section{Source}

National Cancer Institute. Infiltrating Bladder Urothelial Carcinoma, Lipid-Rich Variant. NCI Thesaurus. Code C39828.

A variant of infiltrating bladder urothelial carcinoma characterized by the presence of lipid laden tumor cells. 